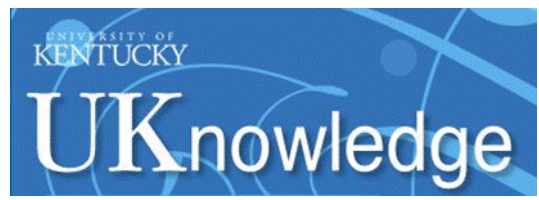

University of Kentucky

UKnowledge

\title{
Some Basics of Capitalism and Socialism and Implications for Human Liberty, Morality, and Fairness
}

John Garen

University of Kentucky, john.garen@uky.edu

Follow this and additional works at: https://uknowledge.uky.edu/isfe_papers

Part of the Economics Commons

Right click to open a feedback form in a new tab to let us know how this document benefits you.

\section{Repository Citation}

Garen, John, "Some Basics of Capitalism and Socialism and Implications for Human Liberty, Morality, and Fairness" (2020). Institute for the Study of Free Enterprise Working Papers. 34.

https://uknowledge.uky.edu/isfe_papers/34

This Research Paper is brought to you for free and open access by the Institute for the Study of Free Enterprise at UKnowledge. It has been accepted for inclusion in Institute for the Study of Free Enterprise Working Papers by an authorized administrator of UKnowledge. For more information, please contact UKnowledge@lsv.uky.edu. 


\section{Some Basics of Capitalism and Socialism and Implications for Human Liberty, Morality, and Fairness}

\section{John Garen}

September 2020

Institute for the Study of Free Enterprise Working Paper 35

University of Kentucky

244 Gatton College of Business and Economics

Lexington, KY 40506-0034 


\title{
Some Basics of Capitalism and Socialism and Implications for Human Liberty, Morality, and Fairness
}

\author{
John Garen* \\ BB\&T Professor of Economics \\ Gatton College of Business and Economics \\ University of Kentucky \\ jgaren@uky.edu
}

September 2020

\begin{abstract}
This essay outlines the big-picture aspects of capitalism and socialism, and uses this overview to discuss human liberty and economic liberty in each system. Additionally, I note that some have argued that capitalism is unfair or immoral and so I consider three specific and common moral standards in this regard. They are: (i) "From each according to his ability, to each according to his needs;" (ii) "People should get what they earn;” and (iii) “'Agreement without conformity' or 'conformity without agreement.”' Capitalism is centered on individual rights and private ownership, while socialism awards decision-making powers to government. The former is consistent with human and economic liberty while the latter is not. Moreover, socialism fares poorly in comparison to capitalism regarding the three moral standards.
\end{abstract}

* This essay expands upon my presentation to the combined Central Kentucky meeting of Americans for Prosperity and the Bluegrass Economic Education Society on July 17, 2019. 
This essay begins with some big-picture aspects of capitalism, or market organization, versus socialism, or government organization. Essentially, capitalism involves individual decision-making power and personal rights, while socialism entails government power in planning people’s lives. Because government planners do not have the knowledge or incentives to serve the populace well, socialism inevitably fails to live up to its promises. Less allencompassing forms of government planning have similar problems, though on a smaller scale.

The big-picture overview is used to discuss the nature of human liberty and of economic liberty, as well as their link to private ownership. Human liberty, including economic liberty, is essentially individual-based, so is consistent with capitalism (and private property) and in conflict with socialism. I also note that, while it is frequently conceded that capitalism brings higher living standards, it is often argued that capitalism is an unfair or immoral system. I consider three specific and common moral standards this regard. One is: "From each according to his ability, to each according to his needs.” Though this is the socialist ideal, socialism fails to attain it. Another adage is: "People should get what they earn.” One this score, capitalism fares well and socialism does not. A third is: “'Agreement without conformity' or 'conformity without agreement.’” Markets (capitalism) promote the former while government (socialism) entails the latter, thus capitalism is superior in generating peaceful collaboration in a society.

\section{The Big Picture of Socialism and Capitalism}

The overarching feature of capitalism is that it imbeds in individuals the rights to plan and act for themselves, acting alone or in voluntary cooperation with others, while respecting the like rights of others. ${ }^{1}$ Socialism removes these rights from individuals such that the government - whatever form it takes - has these powers. Full-fledged socialism does this at a very large

${ }^{1}$ This last phrase is critical. It means, for example, that you do not have the right to steal from others because that is an involuntary imposition on them. 
scale. Consequently, instead of decisions and choices by private individuals and firms, the government plans the amounts and types of goods and services produced, what types of equipment and human resources are used to make them, and where, when, and to whom they are provided or sold. Thus, the role of government is vastly different from that in capitalism, where its focus is enforcing people's rights ${ }^{2}$ and leaving it to individuals to plan for themselves. With socialism, government takes over the latter and has less concern with the former.

Of course, government planners do not have the fine-grained information about you to make informed decisions on your behalf. Nor do government planners have as strong incentives as you do to make good decisions for yourself. After all, you are the one who must live with those decisions. These are the two fundamental problems with government planning and they are colossal ones, indeed. How can someone plan for you if they really don't know you very well and your interests are not central to them?

Thus, government planners invariably get it wrong. Moreover, people are precluded from finding and consummating mutually beneficial transactions, i.e., sellers do not have the authority to produce what they wish and seek out willing buyers and buyers are limited in their options. The predictable result is abysmal economic performance. Fewer and poorer quality goods and services are produced, they come at higher cost, and the result is lower standards of living. Naturally, a lower standard of living means less of everyday goods like food and clothing, in contrast to the much greater availability of such goods under capitalism. But the increased availability of "basic" goods under capitalism empowers individuals and entrepreneurs to produce and consume a much wider and more meaningful set of goods and services. As

\footnotetext{
${ }^{2}$ This is no small task, especially in a large urban society. The constant interactions in large cities often entail numerous potential impositions on one another, including noise, congestion, and trash and sewage disposal. The challenge in such societies is limiting those impositions in acceptable ways.
} 
standards of living grow under capitalism, people invent many new and amazing products in transportation, in communication, in medicine, entertainment, and in many other areas.

Individuals have more time and resources to invest in (or simply enjoy) education and to partake of more entertainment, art, travel, leisure, and charitable and spiritual activity. Life is more readily enjoyed.

Thus, the term "standard of living" has a much deeper meaning than simply food on the table and a roof over your head. The typical citizen in a socialist economy simply does not attain the standard of living of those in capitalist economies and they also have a harsher and less prosperous life. Moreover, each person has less control over their life and any choices they do have are severely restricted.

Some socialist economies have managed to generate the rudiments of a tolerable lifestyle for the average citizen, but have attained but little else. The former socialist countries of Eastern Europe are examples. However, in some cases, the dysfunctionality of the socialist economy is so severe that it produces economic and social collapse that is dire and life-threatening. Venezuela is a recent example.

\section{$\underline{\text { Smaller Scale "Socialism" }}$}

So-called "mixed" economics systems, where government intercedes in personal decision-making in less encompassing ways, still cause economic harm in the sectors of the economy where intervention is the heaviest. ${ }^{3}$ Instead of government "planning," there is government "influence" over production and trade. Good examples are regulations that prevent newcomers from competing, such as limits on entry in markets like hairdressers, taxi cabs, and hospitals and surgery centers. Other examples are prevailing wage laws, wage and price

\footnotetext{
${ }^{3}$ Note by “intervention," I mean government activity that goes beyond the protection of persons and property from the unwanted impositions by others.
} 
controls, and special tax breaks and regulatory favors for special interests. Markets with these burdens have less output, higher costs and prices, and less consumer satisfaction. This puts sand in the gears of capitalism and of individuals' efforts to improve their lot in life.

The famous French author Alexis de Tocqueville expressed concern about a pervasive but less exact form of control by government, where little is explicitly directed by planners, but a myriad of rules and regulations impedes private action:

“ . . . the sovereign power extends its arms over the entire society; it covers the surface of society with a network of small, complicated, minute, and uniform rules, which the most original minds and the most vigorous souls cannot break through to go beyond the crowd; it does not break wills, but it softens them, bends them and directs them; it rarely forces action, but it constantly opposes your acting; it does not destroy, it prevents birth; it does not tyrannize, it hinders, it represses, it enervates, it extinguishes, ..."4

An economy characterized by the above is not capitalism. Government impedes private activities, interferes with the way that one earns an income, and inhibits how one lives their life.

Another illusion of capitalism is where “private” companies are awarded sweetheart contracts from government, are allowed monopolies over certain markets, have special tax and regulatory deals, and are protected from foreign competition. This occurs in various places at various times, often in the low-income countries in Asia, Africa, and Central America, but also in South America. It is regularly accompanied by repression of the media and of political protest and opposition. It frequently occurs where large companies (and their large unions) exert heavy political influence over the government such that it may be hard to see where the government starts and the company ends, i.e., government officials (explicitly or implicitly) may have substantial say over the companies' activities. This is no way, shape, or form a capitalist economy. This is where the economy - and people's lives - is run by government cronies.

\footnotetext{
${ }^{4}$ See https://oll.libertyfund.org/quotes/281.
} 
Another mixed system is social democracy, such as Sweden and other European countries, though it is "mixed" in a different way. Typically in this system, individuals and firms have wide latitude in the decisions about what they buy, the markets they enter and products/services they sell, and in most aspects of their lives. So this is not really socialism. Government planners do not decide the production of most goods and services, where goods are shipped, and who may serve which markets. However, total taxes are very high (50\% or more) such that people simply don't have choices regarding how to enjoy half of their income. The government decides how half is spent. These governments are usually elected by a majoritarian process and people can express their preferences through voting. However, whatever the outcome of the voting process, you get what the majority rules and the resulting government decides. If you are in the minority, you lose. You get what you believe is a bad deal for your money. A common outcome for countries with this type of economy is that government spending goes to schooling, healthcare, and pensions. Though it seems that everyone wants these things, there can be a wide variation regarding the type and amount of desired schooling, healthcare, and pensions. Minority opinions on each of these things still lose out.

\section{Economic Liberties and Human Liberties}

When people speak of human liberties, they often refer to the type of rights delineated in the Bill of Rights, e.g., freedom of the press, freedom of religion, freedom of expression, freedom of assembly, and other related rights. It seems that support for liberties of this sort is widespread. This is quite understandable since your religious beliefs, how you express yourself, your ability to protest, who you associate with, and what you read are surely important. Indeed, they are often deeply felt and can define who you are. Not everyone is passionate about religion, art, literature, or assembly/protesting, but it seems that most agree that government should not 
interfere with these aspects of one's life that may be so personal and life-defining. In other words, individuals decide for themselves.

Why is this view so strongly felt and widely shared? It is most likely for the reason just noted: governments are not in a position to decide what is right for you in matters that may be deeply personal and defining. The specifics of this reasoning are as discussed in the previous section. Government planners do not have the fine-grained information about each person to know what is best for them nor do not have the incentives to act on your behalf as clearly as you do.

This exact line of argument applies to so-called "economic" decisions that people make. Many choices in these respects are personal and self-defining. There are many who are passionate about their occupations and whose work might be a major part of their persona, e.g., "I am a carpenter (or lawyer, or consultant, or landscape architect, etc.)." Others are deeply immersed in running their own business. Still others feel strongly about the way they dress, the style of car they buy, the food they eat, and the items on display in their home. As above, these “economic" decisions may be deeply personal and can define who you are and your lifestyle. In this sense, there is no real distinction from other liberties. Thus, they should be protected from government interference for the same reasons as other liberties are, i.e., individuals, not government, should have the rights to decide for themselves in these respects. This entails a capitalist system.

It is puzzling that many strongly defend the former kind of rights but not the latter. Economic liberties are often abused in many ways: limits on entering occupations, onerous fees and red tape for opening businesses, unnecessary regulation of what you can sell and buy, limits on what you may pay for a product or sell it for, taxes that special interest groups do not pay, and 
so on. These effects on "the economy" are not divorced from individuals' lives. These undermine people in the occupations they may enter, their livelihoods, and how they spend their time and money. All limit the way we live our lives. Advocating for human liberties implies advocating for economic liberties as well.

At the end of the day, capitalism awards individuals both types of liberties. Socialism awards these rights to the government. A socialist government might allow some freedom of individual choice in the non-economic or economic realms, but in the end, government has the control since it may rescind these freedoms.

\section{$\underline{\text { Human Liberties and Property Rights }}$}

The topic of property rights is closely related to this discussion. An alternative term for property rights is ownership. The term sounds rather sterile but, as it turns out, private property rights are a key to human liberty. I am using a broad definition of "property," not in a narrow meaning that refers only to land, buildings, and equipment. Private property rights mean that individuals decide how their assets are used, that they retain the net income from their use, and they may buy or sell as they wish. These are personal rights. The most important "asset" to nearly everyone is themselves: their skill set, work ethic, brainpower, and personality. Private property rights means that you decide how these are used by choosing among jobs, choosing or changing careers, starting a business, engaging in charitable work, or working in the home. In other words, with private property rights, you own you. Property rights to yourself (and to other assets you acquire) are paramount. They are not some device to shield the rich. Indeed, the opposite is true. Deeply respected private property rights protect you from the rich and powerful. 
Socialism, and other significant forms of government control, removes some or all of property rights from individuals and awards them to the government. As more of this occurs, the less protection the individual has from powerful officials in government.

The paradox is that we rely on government to protect our rights, yet a government powerful enough to do so may misuse its powers to usurp our rights. The challenge is to design government to enable it to do the former, yet prevent the latter. This issue has been analyzed a great deal, ${ }^{5}$ but one important way to meet this challenge is to devolve power to individuals as much as possible. This implies an economy rooted in capitalism.

\section{$\underline{\text { Some Issues in Morality and Fairness }}$}

It is regularly acknowledged that capitalism brings higher standards of living to people, but it is often questioned whether the system is moral or fair. A great deal has been written about the morality, fairness, and justice of various economic systems. These discussions are a blend of moral philosophy, political philosophy, and economics. I make no attempt summarize these writings. Rather, I present commentary on three common topics that seem to underlie many discussions of morality and fairness regarding capitalism and markets on one hand, and socialism and government on the other.

\section{"From each according to his ability, to each according to his needs."}

This is the Marxian phrase that is supposed to describe the post-Marxian revolution (socialist) world. Is this a good moral standard?

Perhaps, but in a limited way. After all, families typically operate along these lines to some degree. Not everyone in a family (especially children) are equally capable of providing for its members. Yet those who are of lesser ability, and who contribute less, still attain a roughly

\footnotetext{
${ }^{5}$ For a succinct overview, see Epstein, Richard, “Self-Interest and the Constitution,” Journal of Legal Education, 37(2), June 1987, pp. 153-161.
} 
equal share of the family resources. For example, food or housing space is not rationed according to who brought in the most income. Likewise, close friends often share things without close attention to who bought what. Intuitively, these seem like the right things to do.

But this style of organization does not scale up to large societies, where most people are strangers to one another. Who can judge the abilities and needs of the thousands upon thousands (or millions upon millions) of people in a large society? Is there a government or central authority that can do this for us? Of course, the answer to both of these questions is a decided “no.” No single individual or central authority has such detailed knowledge. Other that a few basics and in major catastrophes like floods and tornados, people’s "needs" are highly varied and nuanced. Moreover, among families and friends, each makes sure the others are not shirking their responsibilities to contribute. In large societies, this accountability is absent because neither strangers nor the government really know you and your activities. Without this accountability, “needs” that people claim will expand. Likewise, people’s underlying abilities and efforts are not known to outsiders. With the expansion of "needs," those who contribute more to the group, due to hard work or ability, find themselves stretched more and more and will be less willing to engage in such efforts.

A government that tries to impose the Marxian phrase onto large societies will find itself arbitrarily taking money from people with largely unknown ability and giving it to other people with largely unknown needs, all the while incentivizing/rewarding its citizens into wanting more and producing less. This is not a moral system. Indeed, it is fundamentally immoral. But this is essentially the socialist economic system where government decides who produces what and who gets it. 


\section{“People should get what they earn."}

I suspect that many people think that this is basically a good moral principle. Of course, an exception to this is regarding truly needy people (e.g., seriously injured or disabled) that no one expects to completely earn their way.

The key to this phrase is the meaning of "what they earn.” Many people seem to have an opinion about what others should earn. For example, one often hears that farmers, teachers, and fire fighters should earn more and that movie stars and football coaches are overpaid. However, mandating this type of thing is simply imposing one's view on what people may be paid ... and on what others are allowed to pay. After all, what one person receives in income is what someone else pays them.

Generally, the most sensible way to construe the above phrase is where individuals attain income equal to the value of what they produce for others. On this score, competitive markets, i.e., capitalism, do very well. Under voluntary exchange, buyers will pay, at most, what they value your services. Competition for your services tends to bid up the price of your services so you gain the full value of what you provide. Note that competition also restrains pricing as well; one cannot easily charge more than one's rivals. If the good you produce is commonplace suggesting that you have lots of competitors - your value added is small and thus you will have a lower income. But fundamentally, free enterprise (capitalism) releases forces that push income toward equaling to the value of services to others. Thus, capitalism does well on meeting this moral standard.

Attaining income through theft, deception, or cheating (i.e., by force of fraud) are not earning it by the above definition, so are counter to this moral principle. People who attain income from theft or deception are not earning what someone else is willing to pay. Though 
such activity occurs in any economic system, it is contrary to the defining nature of capitalism. The latter, of course, is individuals making choices in voluntary collaboration with others.

A similar argument applies to cronyism. Cronyism is, as noted above, a group of special interests that use government to gain special privileges for themselves at the expense of, and by impeding the actions of, others. An important example is using government to stifle competition for your product. This entails preventing potential rivals from selling a similar product and stopping their potential customers from buying it. This is not gaining income by increasing value to others.

One final note on this subject. It is critical to be aware of an important time dimension that often occurs regarding earnings. For example, the owner of an apple orchard may have planted the trees decades ago and spent years nurturing them. Once they mature, many apples grow with much less ongoing effort. At that point, it might seem that the orchard owner has an easy life, just reaping the plentiful harvest and selling them to attain a large income, which is used to buy a beautiful house, a fancy car, and so on. Someone might ask whether this modest effort really is enough to earn the high income and standard of living. Of course, this question ignores the long earlier periods of more strenuous effort and modest income. The present high income is a return on the earlier investment.

The same ideas apply to numerous professions and business, e.g., physicians, lawyers, home repair businesses. Successful professionals and business owners earn high incomes and have high standards of living. But these rewards are the returns on long years of work producing something others want to buy. A current high level of earnings is almost never unearned manna from heaven. It normally comes as a payoff to long years of hard work producing valuable goods or services. 


\section{“'Agreement without conformity' or 'conformity without agreement.'”}

These phrases are rarely used but are important in discussing the outcomes of capitalism versus socialism (or markets versus government). Getting along peacefully with one another is a good outcome. Finding organizing principles that facilitate this is a good thing. One way to do so is coming to agreement with one another.

Even better, can we have “agreement without conformity?” That is, can we agree with one another without all having to do the same thing? As it turns out, this is quite common. I buy black shoes and you buy brown ones; I might listen to country and you to opera; I may prefer chicken to fish and you the opposite; I may read detective novels and you ancient history. I have no problem with your choices and you have none with mine. We agree that we can do things differently, which often means non-conformity. This type of outcome is characteristic of markets. We each do with our money as we wish and let others do the same.

Unfortunately, conformity without agreement is the usual outcome of political/government solutions. These tend to impose one-size-fits-all policies on everyone. Agree or not, your tax dollars pay for the politically-determined outcome. Losers must conform, even though they object to the outcome. To gain what you want requires engaging in the political battle to impose your preferred outcome on everyone else. No amount of civility changes this. Indeed, the nature of political competition exacerbates conflict. Losers go away unhappy because they are precluded from spending their money as they’d really like.

Compromise is possible, but that often means no one really gets what they want. If major issues are decided politically (i.e., by government), discord and embitterment toward your fellow citizens is sure to follow. The system fosters conflict, not peaceful cooperation. This contrasts 
starkly with market outcomes. It's remarkable how much people vary in their purchases of cars, music, food, houses, clothing, books, etc. with barely a whimper of complaint.

For some goods “conformity” is unavoidable. For example, we all have the same U.S. Army. Locally, the road system is identical for everyone. Insect abatement from the city spraying is the same for all. It's impossible for you and me to have different national armies, different levels of insect abatement, or different road systems. Here, there is little alternative to government/political determination. However, these are special cases. Using government beyond such cases only worsens conflict by forcing conformity without agreement where it need not go.

There is no morality in systematically forcing people to pay for government-ordered outcomes that they do not value. Moreover, this is a sure ticket to discord. Use of government to compel such outcomes is not good, fair, or just.

\section{$\underline{\text { Conclusion }}$}

No economic system is pure in its form. Indeed, capitalism requires some essential government functions. Even largely socialist economies allow some individual choice.

Furthermore, most economies are mixed systems, having varying degrees of government versus individual control.

However, outside the essential functions of government in a market economy, greater and greater government intervention in an economy moves a society toward socialism. This, of course, entails fewer and fewer decision rights held by individuals and less human and economic liberty. These make it problematic in attaining better standards of living and in meeting the simple moral standards discussed above. 